\title{
Molecular survey of tick-borne pathogens in small mammals from Brazilian Amazonia
}

\author{
Levantamento molecular de patógenos transmitidos por carrapatos em pequenos \\ mamíferos da Amazônia brasileira
}

Ana Cláudia Colle ${ }^{1}$; Ravena Fernanda Braga de Mendonça²; Maerle Oliveira Maia ${ }^{1}$; Leodil da Costa Freitas ${ }^{1}$; Rute Witter ${ }^{1}$; Arlei Marcili³; Daniel Moura de Aguiar ${ }^{1}$; Sebastián Muñoz-Leal'; Marcelo Bahia Labruna ${ }^{4}$; Rogério Vieira Rossi ${ }^{2,5}$; Richard de Campos Pacheco ${ }^{1 *}$ (1)

\begin{abstract}
${ }^{1}$ Programa de Pós-graduação em Ciências Veterinárias - PPGVET, Faculdade de Medicina Veterinária - FAVET, Universidade Federal de Mato Grosso - UFMT, Cuiabá, MT, Brasil

${ }^{2}$ Programa de Pós-graduação em Ecologia e Conservação da Biodiversidade - PPG-ECB, Instituto de Biociências - IB, Universidade Federal de Mato Grosso - UFMT, Cuiabá, MT, Brasil

${ }^{3}$ Programa de Pós-graduação em Medicina e Bem-Estar Animal, Universidade de Santo Amaro - UNISA, São Paulo, SP, Brasil

${ }^{4}$ Departamento de Medicina Veterinária Preventiva e Saúde Animal - VPS, Faculdade de Medicina Veterinária e Zootecnia - FMVZ, Universidade de São Paulo - USP, São Paulo, SP, Brasil

${ }^{5}$ Laboratório de Mastozoologia, Instituto de Biociências - IB, Universidade Federal de Mato Grosso - UFMT, Cuiabá, MT, Brasil
\end{abstract}

Received May 13, 2019

Accepted September 25, 2019

\begin{abstract}
Small non-volant mammals (marsupials and small rodents) were captured at three different timepoints from 23 forest fragments across three municipalities (Alta Floresta, Sinop and Cláudia) covering the Amazonian biome of the Mato Grosso State in Midwestern Brazil. The animal tissues (liver and spleen) and blood were screened using molecular tools for the detection of Babesia, Coxiella, Cytauxzoon, Hepatozoon, Theileria, and Anaplasmataceae agents. A total of 230 specimens (78 rodents and 152 marsupials) were trapped. Hepatozoon and Piroplasmorida agents were detected in the common opossums (Didelphis marsupialis). In turn, all samples (blood, liver, or spleen) collected from the small mammals were negative for the genus Coxiella and the family Anaplasmataceae, as detected by polymerase chain reaction (PCR). Phylogenetic analyses inferred from partial sequences of the $18 \mathrm{~S}$ rRNA gene highlighted the occurrence of new Hepatozoon and Piroplasmorida haplotypes. Future studies determining the role of common opossum (D. marsupialis) in the epidemiological cycles of Hepatozoon and Babesia under natural conditions in the Amazonian biome are necessary.

Keywords: Hepatozoon, Babesia, Amazonian biome, Mato Grosso state.
\end{abstract}

\section{Resumo}

Pequenos mamíferos não voadores (marsupiais e pequenos roedores) foram capturados em três diferentes períodos, ao longo de 23 fragmentos florestais de três municípios (Alta Floresta, Sinop e Cláudia), localizados no bioma amazônico do Estado de Mato Grosso, no centro-oeste do Brasil. Os tecidos dos animais (fígado e baço) e sangue foram selecionados e submetidos a ensaios moleculares para a deteç̧ão do DNA de Babesia, Coxiella, Cytauxzoon, Hepatozoon, Theileria e agentes Anaplasmataceae. Um total de 230 espécimes (78 roedores e 152 marsupiais) foram capturados. Hepatozoon e agentes Piroplasmorida foram detectados em gambás (Didelphis marsupialis). Ao contrário, todas as amostras (sangue, fígado ou baço) coletadas dos pequenos mamíferos foram negativas para o gênero Coxiella e a família Anaplasmataceae, conforme detectado pela reação em cadeia da polimerase (PCR). Análises filogenéticas inferidas pelas sequências parciais do gene $18 \mathrm{~S}$ rRNA evidenciaram a ocorrência de novos haplótipos de Hepatozoon e Piroplasmorida. Futuros estudos determinando a importância do gambá-comun (D. marsupialis) nos ciclos epidemiológicos de Hepatozoon e Babesia em condiçốes naturais, no bioma amazônico, são necessários.

Palavras-chave: Hepatozoon, Babesia, bioma Amazônico, estado de Mato Grosso.

*Corresponding author: Richard de Campos Pacheco. Programa de

Pós-graduaçâo em Ciências Veterinárias - PPGVET, Faculdade de Medicina

Veterinária - FAVET, Universidade Federal de Mato Grosso - UFMT,

Av. Fernando Corrêa da Costa, 2367, Boa Esperança, CEP 78060-900, Cuiabá,

MT, Brasil. e-mail: richard@ufmt.br 


\section{Introduction}

The interactions between animals, humans, and the environment in which both live are currently recognized as the drivers for a unified health concept, contemporary known as 'One Health' (ROBERTSON et al., 2014). Small mammals are widely distributed vertebrates and ticks constitute common parasites (DURDEN, 2006). A wide variety of vertebrate pathogens (especially certain viruses, bacteria and protozoa) evolved strategies to thrive in transmission cycles that include ticks and associated small mammals hosts (DURDEN \& KEIRANS, 1996; SONENSHINE et al., 2002; DURDEN, 2006).

Vector-borne protozoa of the order Piroplasmorida (e.g. Babesia, Theileria, Cytauxzoon) and suborder Adelorina (e.g. Hepatozoon) represent a group of mammalian blood parasites with highly significant economic, veterinary, and medical impacts (MODRÝ et al., 2017; JALOVECKA et al., 2018). Obligate intracellular coccobacilli pathogenic for certain mammals, including humans, are present in the Anaplasmataceae family of alpha-proteobacteria (DUMLER et al., 2001). Apart from several Candidatus taxa, this family of bacteria currently comprises four recognized genera, namely Anaplasma, Ehrlichia, Neorickettsia, and Wolbachia, of which, the first two are recognized as tick-borne pathogens with relevance in veterinary and public health (DUMLER et al., 2001). The gamma-proteobacterium Coxiella burnetii is the causative agent of Q fever/coxiellosis and chronic endocarditis in humans globally (MAURIN \& RAOULT 1999). Molecular evidence has revealed that C. burnetti infects humans in Brazil (LEMOS et al., 2011), and that wild mammals could act as natural reservoirs for this agent (ROZENTAL et al., 2017; FERREIRA et al., 2018; ZANATTO et al., 2019).

The state of Mato Grosso is located in Midwestern Brazil encompassing an area of approximately $1,000.000 \mathrm{~km}^{2}$ and is a natural habitat for biotic elements of the Amazonia (Amazonian rainforest), Cerrado (Brazilian savannah), and Pantanal (wetlands). The southern Amazonian forests are spread as far as the northern portion of the state and cover nearly $53 \%$ of its territory (IBGE, 2004). It is noteworthy that the Amazonia biome is one of the largest reserves of biodiversity globally (JENKINS et al., 2013) and the largest ecosystem in Brazil (BRASIL, 2010).

Several studies on the Amazonian wildlife have assessed the occurrence of vector-borne protozoans and bacteria. Molecular studies performed on free-ranging vertebrates (HARRIS et al., 2015; FURTADO et al., 2017a, b; SOARES et al., 2017a, b; GOMES et al., 2018) and their associated ticks (SOARES et al., 2015) have already detected the presence of tick-borne agents belonging to the genera Babesia, Coxiella, Cytauxzoon, Hepatozoon and Theileria, and the Anaplasmataceae family of bacteria. While these studies shed light on the occurrence of putative new species of microorganisms and on the implied roles of vertebrate reservoirs, the analyzed samples belonged mainly to reptiles, birds, and large mammals (HARRIS et al., 2015; FURTADO et al., 2017a, b; SOARES et al., 2017a, b; GOMES et al., 2018). In order to assess their roles as carriers for different tick-borne pathogens, in this study, we conducted molecular analyses for the detection of Hepatozoon, Babesia, Theileria, Cytauxzoon, Coxiella and Anaplasmataceae agents in the small, non-volant, understudied mammals (marsupials and small rodents) inhabiting the Amazonia region of the Mato Grosso State.

\section{Materials and Methods}

\section{Study area and sampling procedures}

Samples were collected at three different timepoints from 23 forest fragments across three municipalities covering the Amazonian biome of the Mato Grosso State in Midwestern Brazil (Figure 1). One field expedition was conducted in the Alta Floresta municipality from 29 April to 15 May 2014. The municipalities of Sinop and Cláudia were included in the surveys and were visited simultaneously from 3 November to 1 December 2016, and from 3 July to 1 August 2017. Small non-volant mammals were captured using wire cage traps $(16.5 \mathrm{~cm} \times 16.5 \mathrm{~cm} \times 35 \mathrm{~cm})$ and Sherman-like traps $(9.5 \mathrm{~cm} \times 8 \mathrm{~cm} \times 25 \mathrm{~cm})$, which were distributed as mentioned below.

At each prospected point, we set a line of trap stations comprising alternatively of one Sherman-like and one wire cage trap displayed on the ground or onto vines up to $1.5 \mathrm{~m}$ high. At each of the six points in the Alta Floresta and 17 forest fragments surveyed at Sinop and Cláudia, 13 trap stations (with a total of 26 traps) and 30 trap stations (with a total of 60 traps), respectively were set. Each station was separated from the other by a distance of $10-15 \mathrm{~m}$. The traps were baited with a piece of banana and a mixture of peanut butter, corn flour, sardine oil, and vanilla flavor. All traps were kept active for 16 consecutive days in the Alta Floresta, and 8 consecutive days in the Sinop and Cláudia.

Apart from the Sherman-like and wire cage traps, pitfall traps (60-liter buckets) were installed at each station in the Alta Floresta. For this purpose, we set a line of 10 traps, each separated by a distance of $8 \mathrm{~m}$ from the next and linked by a 60-cm-high drift fence to direct small vertebrates toward the pits. The pitfall traps were kept active for 16 consecutive days.

The traps were checked daily and rebaited whenever necessary. The captured animals were anesthetized with an intramuscular injection of ketamine hydrochloride/xylazine solution. After the onset of anesthesia, blood was collected from the animals via cardiac puncture and preserved with ethanol (1:1 ratio) in sterile polypropylene tubes. All specimens were subsequently euthanized by increasing the anesthetic doses. Thereafter, fragments of their spleens and livers were also collected through laparotomy and placed in separate sterile polypropylene tubes. Blood and tissue samples were stored by freezing at $-20{ }^{\circ} \mathrm{C}$ prior to their transfer to the laboratory for DNA extraction and molecular analyses by polymerase chain reaction (PCR) assays, as detailed below.

Animal handling procedures were conducted as per the guidelines of the American Society of Mammologists for the use of wild mammals in research (SIKES et al., 2016). The marsupials were identified based on the criteria provided by Gardner (2007), except those belonging to the Gracilinanus, Marmosa, Marmosops, and Monodelphis genera, which were identified as per the criteria defined by Semedo et al. (2015), Díaz-Nieto \& Voss (2016), Pavan et al. (2017) and Pavan (2019), respectively, and subgenus Micoureus that was identified based on the criteria provided by Silva et al. (2019). The rodents were identified according to the criteria provided by Patton et al. (2015), except Neacomys, Oecomys, and Oligoryzomys, which were identified based on those provided 


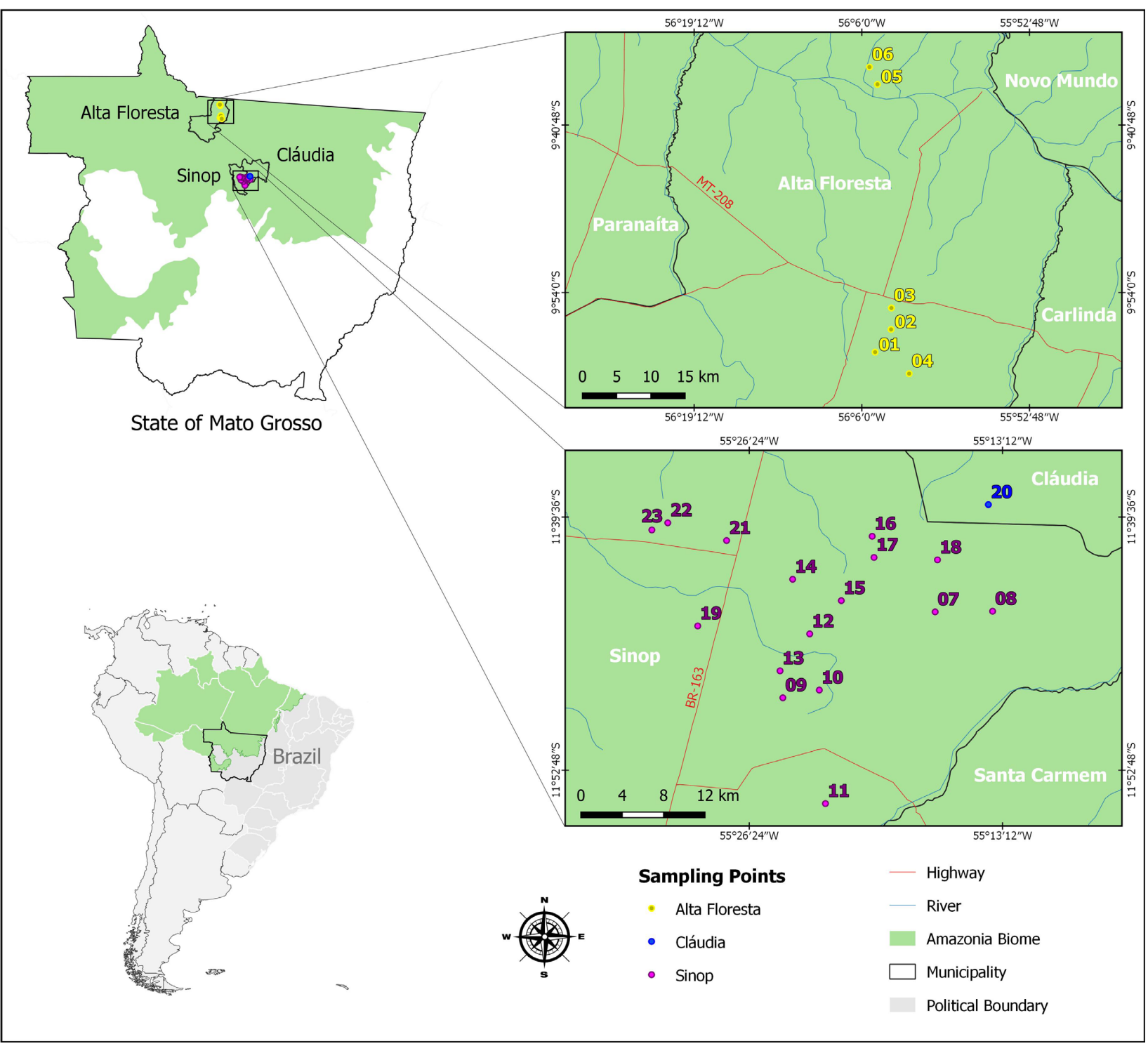

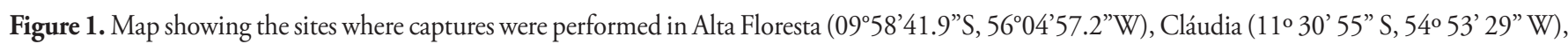
and Sinop (11 $\left.49^{\prime} 1.71^{\prime \prime S}, 55^{\circ} 24^{\prime} 39.05^{\prime} \mathrm{W}\right)$ municipalities within Brazilian Amazonia of the Mato Grosso State, Brazil.

by Hurtado \& Pacheco (2017), Suárez-Villota et al. (2018), and Weksler et al. (2017), respectively. Voucher specimens were deposited in the "Coleção Zoológica da Universidade Federal de Mato Grosso (UFMT)”, Cuiabá, Mato Grosso, Brazil.

Procedures in this study were previously approved by the Ethics Committee on Animal Research of the Federal University of Mato Grosso (CEUA protocol no. 23108.076870/2015-41) and "Instituto Chico Mendes de Conservação da Biodiversidade" (ICMBio permit no. 8863-1).

\section{Molecular analyses}

DNA extraction from the blood, spleen, and liver tissues was carried out using the DNA extraction PureLink ${ }^{\mathrm{TM}}$ Genomic DNA Mini Kit (Thermo Fisher Scientific, Waltham, Massachusetts, USA), according to the manufacturer's instructions. Mock extractions containing nuclease-free water were included as contamination controls. In order to verify the success of extraction, an initial PCR targeting a fragment of the mammalian glyceraldehyde-3-phosphate dehydrogenase ( $g a p d h)$ gene was performed as described previously (BIRKENHEUER et al., 2003). The extracted samples were then subjected to a battery of PCR assays for amplifying fragments of the following three loci: 18S rRNA of Hepatozoon and Piroplasmorida members (Babesia, Theileria, and Cytauxzoon), Coxiella CTP synthase (pyrG), and 16S rRNA from members of the Anaplasmataceae family. Negative controls (nuclease-free water) and appropriate positive controls were included in each reaction as follows: Babesia vogeli, Hepatozoon canis, both obtained from blood of naturally infected dogs (MAIA et al., 2019), Coxiella burnetii (PACHECO et al., 2013) or Ehrlichia canis (AGUIAR et al., 2008). All primer sets used in the present study are listed in Table 1. The PCR assays were performed in a total volume of $50 \mathrm{uL}$, which contained at least $150 \mathrm{ng} \mathrm{uL}$ of target DNA, $20 \mathrm{pmol}$ of each forward and reverse primer (Thermo Fisher Scientific ${ }^{\mathrm{TM}}$, Waltham, Massachusetts, 


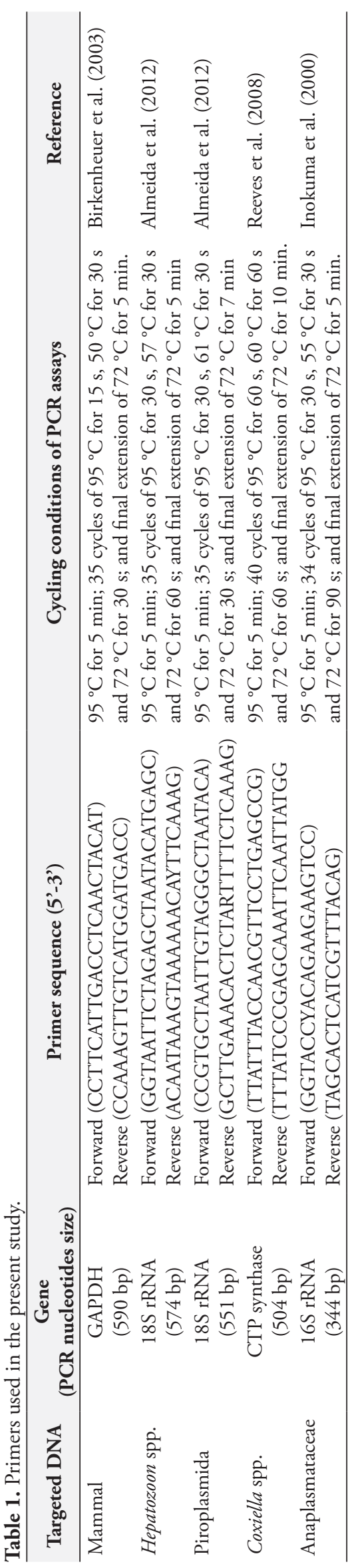


USA), 2U of Taq DNA polymerase (Sigma-Aldrich ${ }^{\mathrm{TM}}$, Darmstadt, Germany), $1 \times$ reaction buffer (Sigma-Aldrich ${ }^{\mathrm{TM}}$, Darmstadt, Germany) containing $1.5 \mathrm{mM} \mathrm{MgCl}_{2}$ and $0.5 \mathrm{mM}$ of deoxynucleotide triphosphate (dNTPs) mixture (Thermo Fisher Scientific ${ }^{\text {TM }}$, Waltham, Massachusetts, USA). The PCR products were resolved in $1.5 \%$ agarose gels stained with the GelRed ${ }^{\mathrm{TM}}$ Nucleic Acid Gel Stain (Biotium, Fremont, California) and visualized in a ChemiDoc XRS system (Bio-Rad, Hercules, California). Amplicons of the expected sizes were purified using the Illustra GFX PCR DNA and Gel Band Purification Kit (GE Healthcare, Chicago, Illinois) and prepared for sequencing as per the instructions provided with the BigDye ${ }^{\mathrm{TM}}$ kit (Applied Biosystems, Foster, California). An ABI-PRISM 3500 Genetic Analyzer (Applied Biosystems, Foster, California) was employed for conducting the sequencing procedures with the same primers used for the PCR. In order to evaluate the quality of the sequences, electropherograms were verified with CLC Genomics Workbench software (Qiagen ${ }^{\circledR}$ ). Obtained sequences were then subjected to a BLAST analyses (ALTSCHUL et al., 1990) in order to infer closest identities with organisms available in GenBank.

\section{Phylogenetic analyses}

Sequences of $18 \mathrm{~S}$ rDNA generated in this study and homologue sequences retrieved from the GenBank were used to construct two alignments, one for the Hepatozoon spp. and another for the Piroplasmorida representatives. The selected sequences were aligned using Clustal X (THOMPSON et al., 1997), and adjusted manually with GeneDoc (NICHOLAS et al., 1997). Two phylogenetic analyses for each alignment were performed. Inferences by maximum parsimony were constructed as per their implementation in PAUP version 4.0b10 (SWOFFORD, 2002), using a heuristic search in 1000 replicates, 500 bootstrap replicates, random stepwise addition starting trees (with random addition sequences) and TBR (tree bisection and reconnection) branch swapping. MrBayes v3.1.2 was used to perform Bayesian analyses (HUELSENBECK \& RONQUIST, 2001) with four independent Markov chain runs for 1,000,000 metropolis-coupled MCMC generations, sampling a tree every $100^{\text {th }}$ generation. The first $25 \%$ of trees represented burn-in, and the remaining trees were used to calculate Bayesian posterior probability. The GTR+I+G was the standard model used in MrBayes software. Sequences of Neospora caninum (L24380; U03069) and Toxoplasma gondii (U03070; L37415) were used as an out-group for the Hepatozoon tree, and Babesia sp. (AF188001) rooted the Piroplasmorida tree. GenBank accession numbers for all sequences used for the phylogenetic analyses were embedded in each tree.

\section{Results}

\section{Capture of mammals, PCR and sequence analyses}

Table 2 provides a list of all captured animals and results of their molecular analyses grouped according to the locality, species and forest fragment. A total of 82 specimens of mammals (32 rodents and 50 marsupials) belonging to at least 11 different species of the order Rodentia and 10 species of the order Didelphimorphia were trapped in the Alta Floresta. At Sinop, 145 specimens (44 rodents and 101 marsupials) belonging to six species of the order Rodentia and seven species of the order Didelphimorphia were captured. Finally, three specimens (2 rodents and one marsupial) belonging to two species of the order Rodentia and one species of the order Didelphimorphia were captured in the areas of the Cláudia municipality. Some of the captured animals perished inside the traps before performing sampling procedures. In these cases, we were unable to take all the samples per specimen (blood, liver, and spleen). Total accounts of samples obtained for each of the captured species are specified in Table 2.

DNA of all 585 samples subjected to gapdh internal control amplified the predicted product. In total, 5.8\% (34/585) of the mammals' samples analyzed were infected by Hepatozoon, while co-infection with Piroplasmorida agents was detected in $0.34 \%$ $(2 / 585)$ of small non-volant mammals trapped. DNA of Hepatozoon was not detected in the samples of mammals captured from the Alta Floresta and Cláudia municipalities; however, at least one tested sample from approximately half $(45.16 \% ; 14 / 31)$ of the common opossums (D. marsupialis) captured at Sinop was positive for this genus of protozoa (Table 2). Among the animals that exhibited positive results for this protozoa, three specimens (field numbers RVR 134, 168 and 255) were positive in all tested samples (blood, spleen and liver); in four specimens (RVR 118, 135, 228 and 256), Hepatozoon DNA was present in both the blood and liver samples; two specimens (field numbers RVR 128 and 130) were positive for Hepatozoon in the blood and spleen; and finally, in five specimens (RVR 153, 154, 156, 159 and 210) only blood samples were positive, as determined by the PCR assay. Because of the quality and the insufficient DNA of amplified samples, it was not possible to sequence $18 \mathrm{~S}$ rRNA amplicons for all Hepatozoonpositive samples. However, only one haplotype was obtained after sequencing products from 14 blood, seven liver, and six spleen samples. This trend was confirmed after aligning all sequences in Clustal X, from which a consensus of 544 base pairs (bp) was retrieved. After BLAST comparisons, this consensus sequence was $96 \%$ identical ( $522 / 544 \mathrm{bp}$ ) to the following four sequences: 1) Hepatozoon sp. isolate HepIxo-281 (MH174345) detected in Ixodes sp. (Acari: Ixodidae) from Chile; 2) Hepatozoon sp. (KY684007) detected in Caiman crocodilus (Crocodylia: Alligatoridae) from Brazilian Amazonia; 3) Hepatozoon sp. DMA-2015 strain Rodent MT (KP757838) detected in Calomys callosus (Rodentia: Cricetidae) from Brazilian Pantanal; and 4) Hepatozoon sp. AS7 (FJ719819) detected in Abrothrix sanborni (Rodentia: Cricetidae) from Chile. The Hepatozoon haplotype generated in the present study was designated as Hepatozoon sp. isolate MTopossum and has been deposited in the GenBank under the accession number MK257775.

Amplicons for Piroplasmorida were not found in any of the samples obtained from mammals captured in the Alta Floresta and Cláudia regions (Table 2). By contrast, Piroplasmorida DNA was detected in two out of 31 blood samples $(6.45 \%)$ of $D$. marsupialis (RVR 130 and 168) trapped at Sinop, both previously positive for Hepatozoon (Table 2). Partial sequences of the $18 \mathrm{~S}$ rRNA gene obtained from these two specimens were identical to each other and presented different identities (94-100\%) against other piroplasmid sequences from the Babesia and Theileria genera. Highest identities 


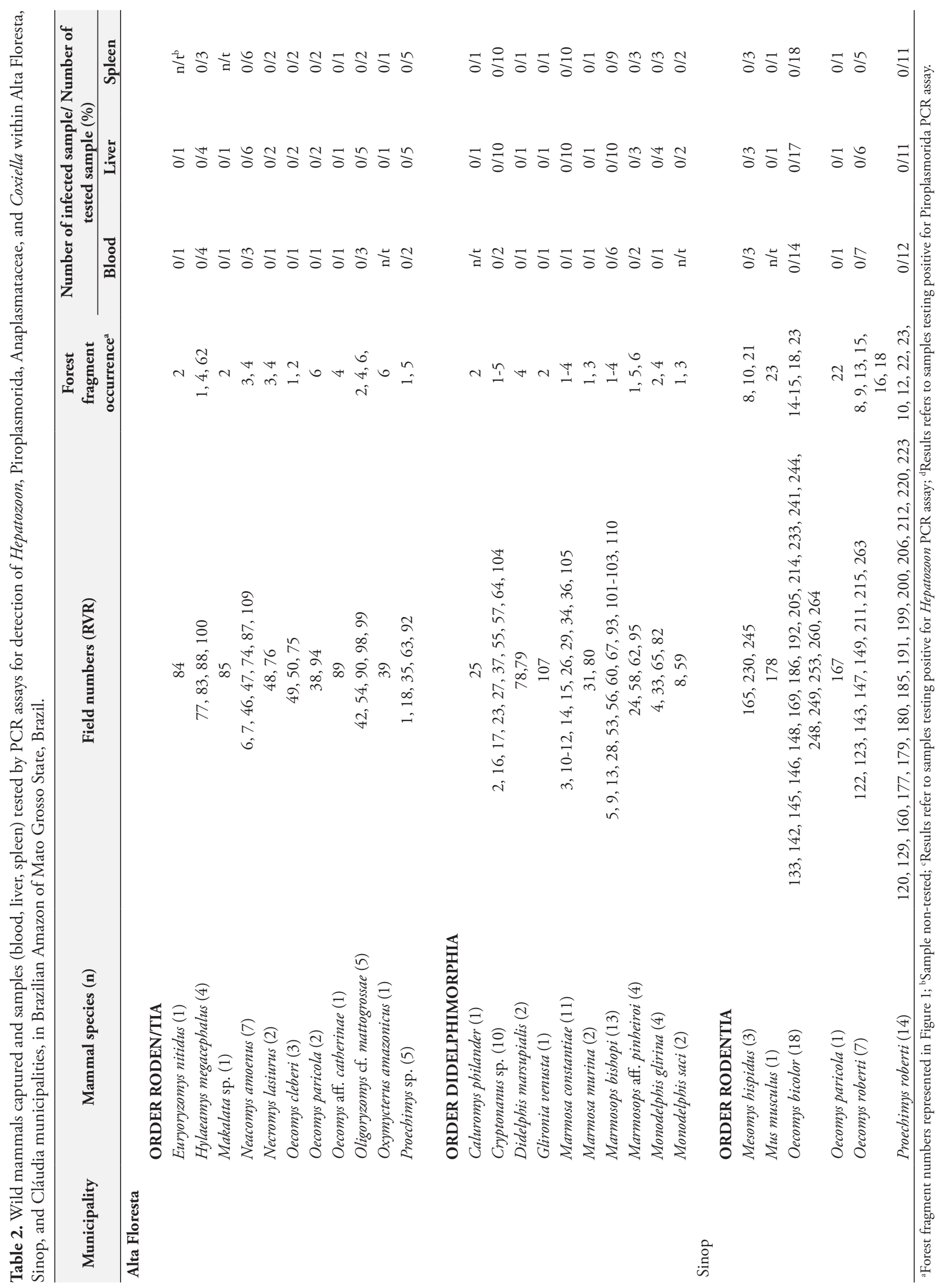




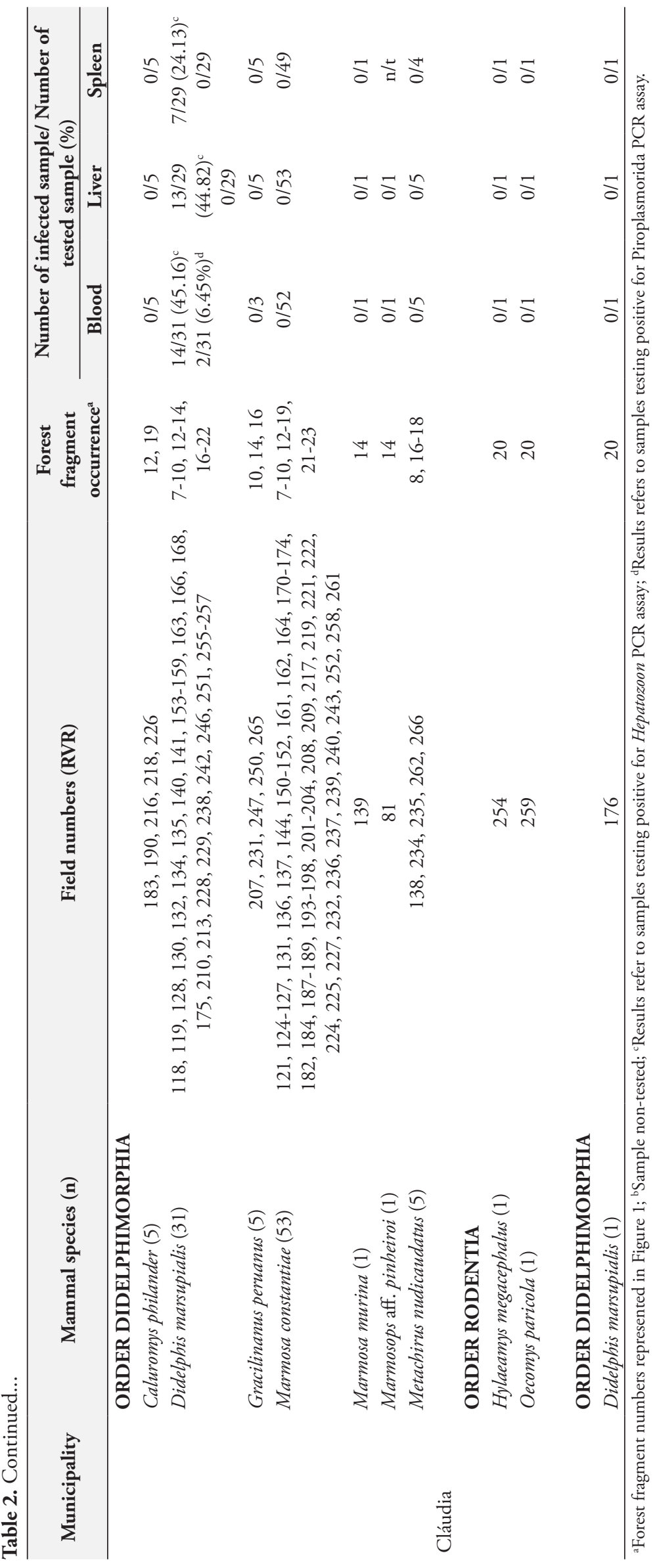


matched (1) a Babesia sp. (KY684002, KP757839) detected in D. marsupialis from the Brazilian Amazonia, and Monodelphis domestica from Brazilian Pantanal; (2) Theileria ornithorhynchi (KT937391) detected in Ornithorhynchus anatinus from Australia; and (3) Theileria bicornis (AF499604) detected in the Black rhinoceros from South Africa.

The GenBank accession number for the partial sequence of $18 \mathrm{~S}$ rRNA gene generated for the Babesia sp. isolate MTopossum in the present study is MK257776.

All samples (blood, liver, or spleen) collected from the small mammals of the Alta Floresta, Sinop and Cláudia municipalities were negative for the genus Coxiella and the family Anaplasmataceae when evaluated using PCR assays.

\section{Phylogenetic analyses}

The phylogenetic analyses inferred from a partial $18 \mathrm{~S}$ rDNA obtained from D. marsupialis indicate that Hepatozoon sp. Mato Grosso forms a clade with a Hepatozoon. sp. recently detected in Ornithodoros atacamensis, a lizard-associated soft tick that occurs in the Atacama Desert, Chile (MUÑOZ-LEAL et al., 2019) (Figure 2). The phylogeny for the Piroplasmorida 18S rRNA gene showed that Babesia sp. Mato Grosso clusters with two congeneric haplotypes, a Babesia sp. also detected in D. marsupialis (KY684002) from the Brazilian Amazonia (SOARES et al., 2017b) and Babesia sp. Monodelphis, characterized from $M$. domestica (KP757839) in the Pantanal biome (WOLF et al., 2016) (Figure 3).

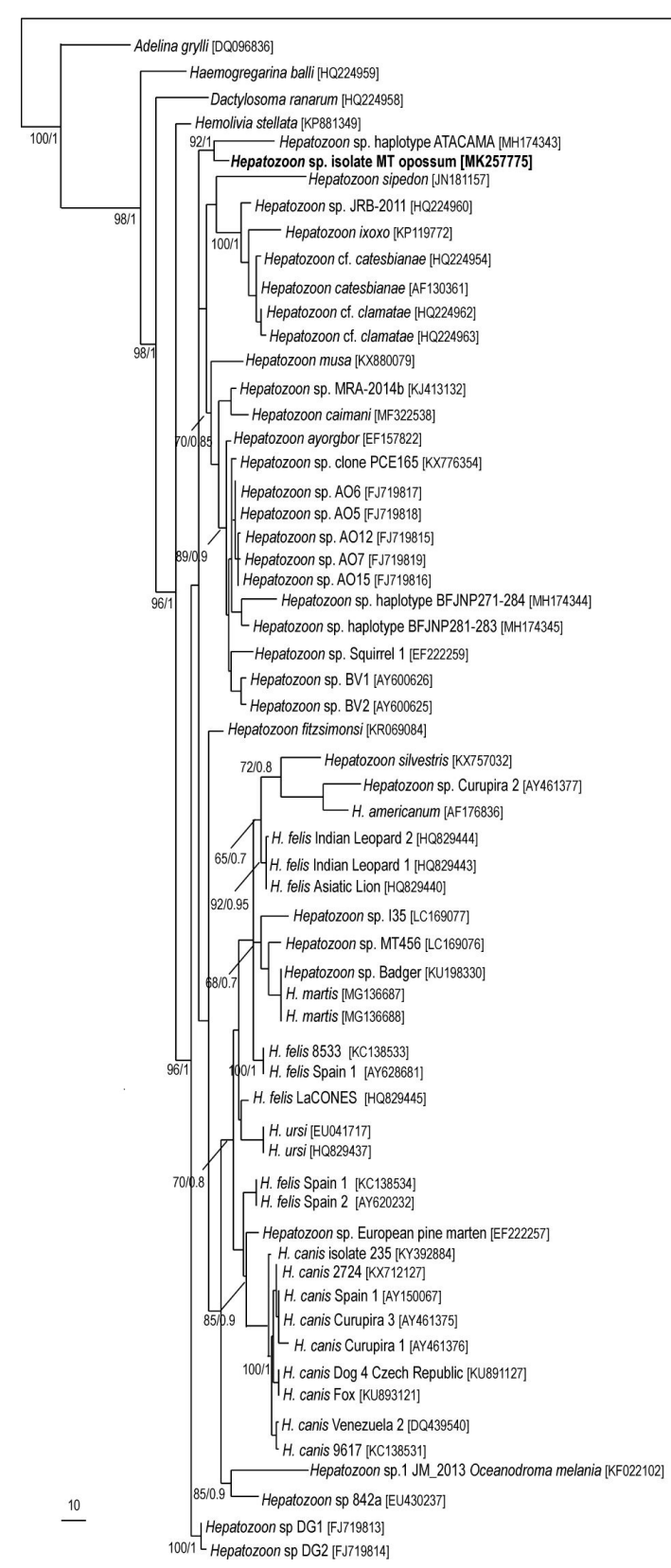

Figure 2. Maximum parsimony and Bayesian tree constructed for an alignment of sequences of Hepatozoon spp. using $18 \mathrm{~S}$ rRNA gene sequences ( $467 \mathrm{bp}$ ). Numbers at nodes are the support values for the major branches (bootstrap over 500 replicates). The sequence obtained in this study is highlighted in bold. Numbers in brackets correspond to GenBank accession numbers. 


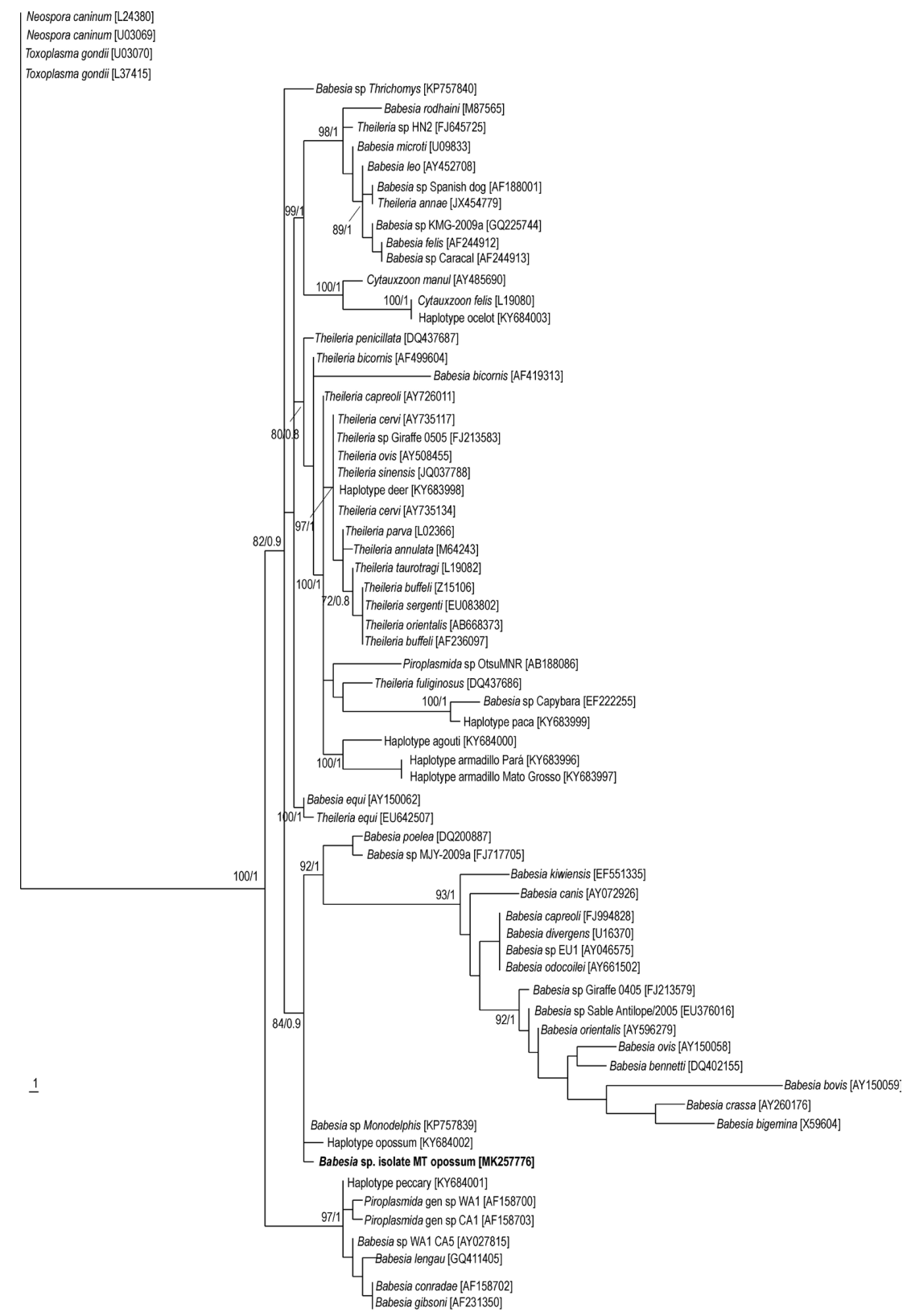

Figure 3. Maximum parsimony and Bayesian tree constructed for an alignment of sequences of Piroplasmorida (Babesia spp., Theileria spp., and Cytauxzoon spp.) species using $18 \mathrm{~S}$ rRNA gene sequences (374 bp). Numbers at nodes are the support values for the major branches (bootstrap over 500 replicates). The sequence obtained in this study is highlighted in bold. Numbers in brackets correspond to GenBank accession numbers.

\section{Discussion}

With the exception of Hepatozoon and Babesia, DNA from tick-borne pathogens (Coxiella, Anaplasma, and Ehrlichia) was not detected in the blood or tissues sampled from the rodents and marsupials. Contrarily, previous studies performed on reptiles, birds, and mammals exposed a variety of genetically distinct organisms of the Anaplasmataceae family circulating in the Amazonian wildlife under natural conditions, which included those of the Cavia sp. (Rodentia: Caviidae) and Marmosa demerarae (Didelphimorphia: Didelphidae) (SOARES et al., 2017a). Therefore, M. demerarae encompassed the host species sampled in the present study.

Our negative results may be related to the low specificity and sensitivity of the conventional PCR (cPCR) assays used for screening. On the other hand, the role of small mammals (rodents and marsupials) as natural reservoirs of these pathogens in nature has not yet proven in Brazil. Indeed, Benevenute et al. 
(2017) surveyed the presence of Anaplasmataceae agents in wild and synanthropic rodents from five different biomes in the country, and observed a low occurrence of Ehrlichia (0.44\%) and Anaplasma (2.4\%) among sampled rodents, while low occurrence of Coxiella (4.6\%) have also been described by Rozental et al. (2017) infecting wild rodents in eight municipalities of Rio de Janeiro state. This trend has also evidenced in other studies conducted in the Brazilian Pantanal biome (WOLF et al., 2016; SOUSA et al., 2017). Furthermore, Benevenute et al. (2017) observed differences between cPCR assay targeting $16 \mathrm{~S}$ rRNA gene and a real-time multiplex PCR (qPCR) focusing amplifications of a fragment of groEL gene, probably given the lower sensitivity of cPCR assays when compared to qPCR assays.

Unlike Perles et al. (2019) that have reported the occurrence of six haplotypes after analyses performed with available $18 \mathrm{~S}$ rRNA Hepatozoon sequences detected in rodents from five Brazilian biomes, in the present study, despite the high prevalence of Hepatozoon (45.16\%) among D. marsupialis from Sinop, a single haplotype of Hepatozoon was retrieved from all positive common opossums. Based on phylogenetic analyses, this haplotype could possibly correspond to a new species. In Brazil, Hepatozoon DNA has already been detected in rodents (i. e. Calomys callosus, Oecomys mamorae) and marsupials (Thylamys macrurus) from the Pantanal biome of the Mato Grosso and Mato Grosso do Sul states (WOLF et al., 2016; SOUSA et al., 2017). Likewise, in the southeastern region of the country (São Paulo state), two distinct Hepatozoon genotypes (Hepatozoon sp. genotype Rodent SP-1 and Hepatozoon sp. genotype Rodent SP-2) have been recorded in Hepatozoon-positive rodents (i.e. Oligoryzomys nigripes, Oligoryzomys flavescens, Akodon sp., Necromys lasiurus, and Sooretamys angouya) by Demoner et al. (2016), while Hepatozoon canis and a new species, named Hepatozoon milleri sp. nov. have been detected in Didelphis albiventris and Akodon montensis, respectively (SILVA et al., 2017; DEMONER et al., 2019). However, to the best of our knowledge, here we provide the first report on the molecular detection of Hepatozoon in D. marsupialis. A common species of Hepatozoon, namely Hepatozoon didelphydis, that infects neotropical marsupials (such as D. albiventris, D. aurita, D. marsupialis, Philander opossum, and Metachirus nudicaudatus) has already been described in French Guiana (THOISY et al., 2000), Colombia (AYALA et al., 1973), and Brazil (SILVA \& ARANTES, 1916). However, these reports were based only on morphological analyses through microscopical observations of blood smears, and could therefore represent different Hepatozoon species (MERINO et al., 2008). A study of blood smears from the opossum Thylamys elegans captured in Central Chile, using light microscopy, conducted by the later authors, identified $H$. didelphydis as well. Based on molecular analyses, this organism was subsequently assigned to the family Sarcocystidae (MERINO et al., 2008). Therefore, molecular methods should be used to identify Hepatozoon agents discovered by optical observation and to further assess the geographical distribution of new haplotypes among marsupials.

The piroplasmid haplotype detected in the common opossum (D. marsupialis), herein designated Babesia sp. isolate MTopossum, was identical to a Babesia haplotype reported recently in a common opossum from the state of Pará (SOARES et al., 2017b). This fact suggests that the currently detected agent could have a broad distribution within the Amazonia. Additionally, infection by the piroplasmid Babesia brasiliensis, determined through morphological characterization, was described in D. marsupialis from the Caribbean coast until the Amazon forest (DEANE \& DEANE, 1961; HERRERA \& URDANETA-MORALES, 1991). Soares et al. (2017b) had suggested that the Babesia haplotypes detected in opossums belonging to the Amazon and Pantanal biomes (WOLF et al., 2016) could correspond to B. brasiliensis. However, until a genetic characterization of $B$. brasiliensis from its type host and locality is available, any comparison based on morphology should be considered as speculative.

Despite recent reports of infection by piroplasmid and Hepatozoon agents among Brazilian wildlife (HARRIS et al., 2015; FURTADO et al., 2017a,b; SOARES et al., 2017a,b; GOMES et al., 2018), our knowledge on these agents is still insufficient. Notwithstanding, the involvement of common opossums (D. marsupialis) in the epidemiology of Hepatozoon spp. and Babesia spp. in the Amazonian biome is a remarkable fact that needs further studies.

Since negative results were observed in at least 224 small mammals tested for Anaplasmataceae and Coxiella agents, this finding is contrary to the results obtained among other vertebrate groups belonging to the same biome (SOARES et al., 2017a). This fact suggests that the role of species screened in this study as reservoirs of these agents is limited, particularly in the areas studied by us.

\section{Conclusion}

The present study provided the first report on the molecular detection of Hepatozoon in common opossum (D. marsupialis) and showed a high occurrence of Hepatozoon spp. among D. marsupialis from Brazilian Amazonia. Furthermore, phylogenetic analyses inferred from partial sequences of the $18 \mathrm{~S}$ rRNA gene highlighted the occurrence of new Hepatozoon and Piroplasmorida haplotypes infecting common opossum. Future studies determining the importance of $D$. marsupialis in the epidemiological cycles of Hepatozoon and Babesia under natural conditions, in the Amazonian biome, are necessary.

\section{Acknowledgements}

This work was supported by the Brazilian funding agencies $\mathrm{CNPq}$ - Conselho Nacional de Desenvolvimento Científico e Tecnológico (Process no. 447557/2014-9 and no. 310352/2016-9), Fundação de Amparo à Pesquisa do Estado de Mato Grosso - FAPEMAT (grants \#568520/2014 and \#477017/2011). The authors gratefully acknowledge Mr. Luiz Valdenir Pinheiro da Silva, owner of Farm São Simão for logistic support during field work and Jeison Lisboa, João Pedro M. Bottan, Juliane Saldanha, Luan G. L. Silva, Ricardo Firmino, Vinícius Terres for their valuable help during field sampling of small mammals. 


\section{References}

Aguiar DM, Hagiwara MK, Labruna MB. In vitro isolation and molecular characterization of an Ehrlichia canis strain from São Paulo, Brazil. Braz J Microbiol 2008; 39(3): 489-493. http://dx.doi.org/10.1590/ S1517-83822008000300014. PMid:24031251.

Almeida AP, Marcili A, Leite RC, Nieri-Bastos FA, Domingues LN, Martins JR, et al. Coxiella symbiont in the tick Ornithodoros rostratus (Acari: argasidae). Ticks Tick Borne Dis 2012; 3(4): 203-206. http:// dx.doi.org/10.1016/j.ttbdis.2012.02.003. PMid:22480930.

Altschul SF, Gish W, Miller W, Myers EW, Lipman DJ. Basic local alignment search tool. J Mol Biol 1990; 215(3): 403-410. http://dx.doi. org/10.1016/S0022-2836(05)80360-2. PMid:2231712.

Ayala SC, D’Alessandro A, Mackenzie R, Angel D. Hemoparasite infections in 830 wild animals from the eastern Llanos of Colombia. J Parasitol 1973; 59(1): 52-59. http://dx.doi.org/10.2307/3278571. PMid:4631557.

Benevenute JL, Dumler JS, Ogrzewalska M, Roque ALR, Mello VVC, Sousa KCM, et al. Assessment of a quantitative $5^{\prime}$ nuclease real-time polymerase chain reaction using groEL gene for Ehrlichia and Anaplasma species in rodents in Brazil. Ticks Tick Borne Dis 2017; 8(4): 646-656. http://dx.doi.org/10.1016/j.ttbdis.2017.04.011. PMid:28457822.

Birkenheuer AJ, Levy MG, Breitschwerdt EB. Development and evaluation of a seminested PCR for detection and differentiation of Babesia gibsoni (Asian genotype) and B. canis DNA in canine blood samples. J Clin Microbiol 2003; 41(9): 4172-4177. http://dx.doi. org/10.1128/JCM.41.9.4172-4177.2003. PMid:12958243.

Brasil. Ministério do Meio Ambiente. Biomas brasileiros 2010 [online]. Brasília: MMA; 2010 [cited 2019 Apr 14]. Available from: http://www. brasil.gov.br/sobre/geografia/biomas-e-vegetacao/biomas-brasileiros

Deane LM, Deane MP. Sobre dois hemocitozoários encontrados em mamíferos silvestres da Região Amazônica. Rev Inst Med Trop São Paulo 1961; 3(3): 107-110.

Demoner LC, Magro NM, Silva MRL, Antunes JMAP, Calabuig CIP, O'Dwyer LH. Hepatozoon spp. infections in wild rodents in an area of endemic canine hepatozoonosis in southeastern Brazil. Ticks Tick Borne Dis 2016; 7(5): 859-864. http://dx.doi.org/10.1016/j. ttbdis.2016.04.002. PMid:27091081.

Demoner LC, Magro NM, Silva MRL, Antunes JMAP, Calabuig CIP, O’Dwyer LH. Hepatozoon milleri sp. nov. (Adeleorina: Hepatozoidae) in Akodon montensis (Rodentia: Cricetidae: Sigmodontinae) from southeastern Brazil. Parasitology 2019; 146(5): 662-669. http://dx.doi. org/10.1017/S0031182018001956. PMid:30486906.

Díaz-Nieto JF, Voss RS. A revision of the didelphid marsupial genus Marmosops, part 1. Species of the subgenus Sciophanes. Bull Am Mus Nat Hist 2016; 402(334): 1-70. http://dx.doi.org/10.1206/00030090-402.1.1.

Dumler JS, Barbet AF, Bekker CP, Dasch GA, Palmer GH, Ray $\mathrm{SC}$, et al. Reorganization of genera in the families Rickettsiaceae and Anaplasmataceae in the order Rickettsiales: unification of some species of Ehrlichia with Anaplasma, Cowdria with Ehrlichia and Ehrlichia with Neorickettsia, descriptions of six new species combinations and designation of Ehrlichia equi and 'HGE agent' as subjective synonyms of Ehrlichia phagocytophila. Int J Syst Evol Microbiol 2001; 51(Pt 6): 2145-2165. http://dx.doi.org/10.1099/00207713-51-6-2145. PMid:11760958.
Durden LA, Keirans JE. Host-parasite coextinction and the plight of tick conservation. Am Entomol (Lanham Md) 1996; 42(2): 87-91. http://dx.doi.org/10.1093/ae/42.2.87.

Durden LA. Taxonomy, host associations, life cycles and vectorial importance of ticks parasitizing small mammals. In: Morand S, Krasnov BR, Poulin R. Micromammals and macroparasites: from evolutionary ecology to management. New York: Springer-Verlag; 2006. p. 91-102. http://dx.doi.org/10.1007/978-4-431-36025-4_6.

Ferreira MS, Guterres A, Rozental T, Novaes RLM, Vilar EM, Oliveira RC, et al. Coxiella and Bartonella spp. in bats (Chiroptera) captured in the Brazilian Atlantic Forest biome. BMC Vet Res 2018; 14(1): 279. http://dx.doi.org/10.1186/s12917-018-1603-0. PMid:30200947.

Furtado MM, Metzger B, Jácomo ATA, Labruna MB, Martins TF, O'Dwyer LH, et al. Hepatozoon spp. infect free-ranging jaguars (Panthera onca) in Brazil. J Parasitol 2017a; 103(3): 243-250. http:// dx.doi.org/10.1645/16-99. PMid:28207298.

Furtado MM, Taniwaki SA, Metzger B, Paduan KS, O’Dwyer LH, Jácomo ATA, et al. Is the free-ranging jaguar (Panthera onca) a reservoir for Cytauxzoon felis in Brazil? Ticks Tick Borne Dis 2017b; 8(4): 470476. http://dx.doi.org/10.1016/j.ttbdis.2017.02.005. PMid:28196774.

Gardner AL. Mammals of South America. Vol. 1. Chicago: The University of Chicago Press; 2007. 690 p.

Gomes LA, Moraes LA, Aguiar DCF, Dias HLT, Ribeiro ASS, Rocha HPC, et al. Genetic diversity of Hepatozoon spp. in Hydrochoerus hydrochaeris and Pecari tajacu from eastern Amazon. Ticks Tick Borne Dis 2018; 9(2): 314-318. http://dx.doi.org/10.1016/j.ttbdis.2017.11.005. PMid:29174447.

Harris DJ, Borges-Nojosa DM, Maia JP. Prevalence and diversity of Hepatozoon in native and exotic geckos from Brazil. J Parasitol 2015; 101(1): 80-85. http://dx.doi.org/10.1645/14-522.1. PMid:25169765.

Herrera L, Urdaneta-Morales S. Didelphis marsupialis: reservoir of Babesia brasiliensis in the valley of Caracas (Venezuela). Acta Cient Venez 1991; 42(1): 45-46. PMid:1843558.

Huelsenbeck JP, Ronquist F. MRBAYES: bayesian inference of phylogenetic trees. Bioinformatics 2001; 17(8): 754-755. http://dx.doi.org/10.1093/ bioinformatics/17.8.754. PMid:11524383.

Hurtado N, Pacheco V. Revision of Neacomys spinosus (Thomas, 1882) (Rodentia: Cricetidae) with emphasis on Peruvian populations and the description of a new species. Zootaxa 2017; 4242(3): 401-440. http:// dx.doi.org/10.11646/zootaxa.4242.3.1. PMid:28610159.

Inokuma H, Raoult D, Brouqui P. Detection of Ehrlichia platys DNA in brown dog ticks (Rhipicephalus sanguineus) in Okinawa Island, Japan. J Clin Microbiol 2000; 38(11): 4219-4221. PMid:11060094.

Instituto Brasileiro de Geografia e Estatística - IBGE. Mapa de biomas $e$ de vegetação [online]. Rio de Janeiro: IBGE; 2004 [cited 2019 Apr 14]. Available from: https://ww2.ibge.gov.br/home/presidencia/ noticias/21052004biomashtml.shtm

Jalovecka M, Hajdusek O, Sojka D, Kopacek P, Malandrin L. The complexity of piroplasms life cycles. Front Cell Infect Microbiol 2018; 8: 248. http://dx.doi.org/10.3389/fcimb.2018.00248. PMid:30083518.

Jenkins CN, Pimm SL, Joppa LN. Global patterns of terrestrial vertebrate diversity and conservation. Proc Natl Acad Sci USA 2013 110(28): E2602-E2610. http://dx.doi.org/10.1073/pnas.1302251110. PMid:23803854. 
Lemos ER, Rozental T, Mares-Guia MA, Almeida DN, Moreira N, Silva RG, et al. Q fever as a cause of fever of unknown origin and thrombocytosis: first molecular evidence of Coxiella burnetii in Brazil. Vector Borne Zoonotic Dis 2011; 11(1): 85-87. http://dx.doi.org/10.1089/ vbz.2009.0261. PMid:20569012.

Maia MO, Freitas ALS, Santos JG, Pacheco TA, Ramos DGS, Silva GCP, et al. Molecular survey of Babesia vogeli and Hepatozoon species in dogs from urban area of Midwestern Brazil. Semina: Ciênc Agrár 2019; 40(3): 1357-1364. http://dx.doi.org/10.5433/1679-0359.2019v40n3p1357.

Maurin M, Raoult D. Q fever. Clin Microbiol Rev 1999; 12(4): 518553. http://dx.doi.org/10.1128/CMR.12.4.518. PMid:10515901.

Merino S, Vásquez RA, Martínez J, Celis-Diez JL, Martínez-de la Puente J, Marín-Vial P, et al. A Sarcocystid misidentified as Hepatozoon didelphydis: molecular data from a parasitic infection in the blood of the Southern mouse opossum (Thylamys elegans) from Chile. J Eukaryot Microbiol 2008; 55(6): 536-540. http://dx.doi.org/10.1111/j.15507408.2008.00358.x. PMid:19120800.

Modrý D, Beck R, Hrazdilová K, Baneth G. A review of methods for detection of Hepatozoon infection in carnivores and arthropod vectors. Vector Borne Zoonotic Dis 2017; 17(1): 66-72. http://dx.doi.org/10.1089/ vbz.2016.1963. PMid:28055571.

Muñoz-Leal S, Lopes MG, Marcili A, Martins TF, González-Acuña D, Labruna MB. Anaplasmataceae, Borrelia and Hepatozoon agents in ticks (Acari: Argasidae, Ixodidae) from Chile. Acta Trop 2019; 192: 91-103. http://dx.doi.org/10.1016/j.actatropica.2019.02.002. PMid:30735640.

Nicholas KB, Nicholas HB, Deerfield DW. GeneDoc: analysis and visualization of genetic variation. Embnew News 1997; 4: 14.

Pacheco RC, Echaide IE, Alves RN, Beletti ME, Nava S, Labruna MB. Coxiella burnetii in ticks, Argentina. Emerg Infect Dis 2013; 19(2): 344346. http://dx.doi.org/10.3201/eid1902.120362. PMid:23343647.

Patton JL, Pardiñas UFJ, D’Elía G. Mammals of South America. Vol. 2. Chicago: The University of Chicago Press; 2015. 1336 p.

Pavan SE, Mendes-Oliveira AC, Voss RS. A new species of Monodelphis (Didelphimorphia: Didelphidae) from the Brazilian Amazon. Am Mus Novit 2017; 3872(3872): 1-20. http://dx.doi.org/10.1206/3872.1.

Pavan SE. A revision of the Monodelphis glirina group (Didelphidae: Marmosini), with a description of a new species from Roraima, Brazil. J Mammal 2019; 100(1): 103-117. http://dx.doi.org/10.1093/ jmammal/gyy 165 .

Perles L, Roque ALR, D’Andrea PS, Lemos ERS, Santos AF, Morales AC, et al. Genetic diversity of Hepatozoon spp. in rodents from Brazil. Sci Rep 2019; 9(1): 10122. http://dx.doi.org/10.1038/s41598-01946662-2. PMid:31300712.

Reeves WK, Loftis AD, Nicholson WL, Czarkowski AG. The first report of human illness associated with the Panola Mountain Ehrlichia species: a case report. J Med Case Reports 2008; 2(1): 139. http://dx.doi. org/10.1186/1752-1947-2-139. PMid:18447934.

Robertson LJ, Utaaker KS, Goyal K, Sehgal R. Keeping parasitology under the One Health umbrella. Trends Parasitol 2014; 30(8): 369372. http://dx.doi.org/10.1016/j.pt.2014.06.002. PMid:25022215.

Rozental T, Ferreira MS, Guterres A, Mares-Guia MA, Teixeira BR, Gonçalves J, et al. Zoonotic pathogens in Atlantic Forest wild rodents in Brazil: Bartonella and Coxiella infections. Acta Trop 2017; 168: 64-73. http://dx.doi.org/10.1016/j.actatropica.2017.01.003. PMid:28077317.
Semedo TBF, Brandão MV, Carmignotto AP, Nunes MS, Farias IP, Silva MNF, et al. Taxonomic status and phylogenetic relationships of Marmosa agilis peruana Tate, 1931 (Didelphimorphia: Didelphidae), with comments on the morphological variation of Gracilinanus from central-western Brazil. Zool J Linn Soc 2015; 173(1): 190-216. http:// dx.doi.org/10.1111/zoj.12203.

Sikes RS, Bryan JA, Byman D, Danielson BJ, Eggleston J, Gannon MR, et al. 2016 Guidelines of the American Society of Mammalogists for the use of wild mammals in research and education. J Mammal 2016; 97(3): 663-688. http://dx.doi.org/10.1093/jmammal/gyw078. PMid:29692469.

Silva LGL, Ferreira DC, Rossi RV. Species diversity of Marmosa subgenus Micoureus (Didelphimorphia, Didelphidae) and taxonomic evaluation of the white-bellied woolly mouse opossum, Marmosa constantiae. Zool J Linn Soc 2019; 187(1): 240-277. http://dx.doi.org/10.1093/ zoolinnean/zlz023.

Silva MRL, Fornazari F, Demoner LC, Teixeira CR, Langoni H, O’Dwyer LH. Didelphis albiventris naturally infected with Hepatozoon canis in southeastern Brazil. Ticks Tick Borne Dis 2017; 8(6): 878-881. http:// dx.doi.org/10.1016/j.ttbdis.2017.07.005. PMid:28728938.

Silva OU, Arantes JB. Sobre uma hemogregarina da gambá: hemogregarina didelphydis n. sp. Mem Inst Oswaldo Cruz 1916; 8(2): 61-63. http:// dx.doi.org/10.1590/S0074-02761916000200004.

Soares HS, Barbieri AR, Martins TF, Minervino AH, de Lima JT, Marcili A, et al. Ticks and rickettsial infection in the wildlife of two regions of the Brazilian Amazon. Exp Appl Acarol 2015; 65(1): 125-140. http:// dx.doi.org/10.1007/s10493-014-9851-6. PMid:25273064.

Soares HS, Marcili A, Barbieri ARM, Minervino AHH, Malheiros AF, Gennari SM, et al. Novel Anaplasma and Ehrlichia organisms infecting the wildlife of two regions of the Brazilian Amazon. Acta Trop 2017a; 174: 82-87. http://dx.doi.org/10.1016/j.actatropica.2017.07.006. PMid:28690147.

Soares HS, Marcili A, Barbieri ARM, Minervino AHH, Moreira TR, Gennari SM, et al. Novel piroplasmid and Hepatozoon organisms infecting the wildlife of two regions of the Brazilian Amazon. Int J Parasitol Parasites Wildl 2017b; 6(2): 115-121. http://dx.doi.org/10.1016/j. ijppaw.2017.05.002. PMid:28603688.

Sonenshine DE, Lane RS, Nicholson WL. Ticks (Ixodida). In: Mullen G, Durden L. Medical and veterinary entomology. San Diego: Academic Press; 2002. p. 517-558. http://dx.doi.org/10.1016/B978-0125104517/50026-8.

Sousa KCM, Calchi AC, Herrera HM, Dumler JS, Barros-Battesti DM, Machado RZ, et al. Anaplasmataceae agents among wild mammals and ectoparasites in Brazil. Epidemiol Infect 2017; 145(16): 3424-3437. http://dx.doi.org/10.1017/S095026881700245X. PMid:29103397.

Suárez-Villota EY, Carmignotto AP, Brandão MV, Percequillo AR, Silva MJJ. Systematics of the genus Oecomys (Sigmodontinae: Oryzomyini): molecular phylogenetic, cytogenetic and morphological approaches reveal cryptic species. Zool J Linn Soc 2018; 184(1): 182-210. http:// dx.doi.org/10.1093/zoolinnean/zlx095.

Swofford DL. PAUP: Phylogenetic analysis using parsimony. Beta Version 4.0610. Sunderland: Sinauer and Associates; 2002.

Thoisy B, Michel JC, Vogel I, Vié JC. A survey of hemoparasite infections in free-ranging mammals and reptiles in French Guiana. $J$ Parasitol 2000; 86(5): 1035-1040. http://dx.doi.org/10.1645/00223395(2000)086[1035:ASOHII]2.0.CO;2. PMid:11128476. 
Thompson JD, Gibson TJ, Plewniak F, Jeanmougin F, Higgins DG. The CLUSTAL_X windows interface: flexible strategies for multiple sequence alignment aided by quality analysis tools. Nucleic Acids Res 1997; 25(24): 4876-4882. http://dx.doi.org/10.1093/nar/25.24.4876. PMid:9396791.

Weksler M, Lemos EMS, D’Andrea PS, Bonvicino CR. The taxonomic status of Oligoryzomys mattogrossae (Allen 1916) (Rodentia: Cricetidae: Sigmodontinae), reservoir of Anajatuba Hantavirus. Am Mus Novit 2017; 3880(3880): 1-32. http://dx.doi.org/10.1206/3880.1.
Wolf RW, Aragona M, Muñoz-Leal S, Pinto LB, Melo ALT, Braga IA, et al. Novel Babesia and Hepatozoon agents infecting non-volant small mammals in the Brazilian Pantanal, with the first record of the tick Ornithodoros guaporensis in Brazil. Ticks Tick Borne Dis 2016; 7(3): 449456. http://dx.doi.org/10.1016/j.ttbdis.2016.01.005. PMid:26782931.

Zanatto DCS, Duarte JMB, Labruna MB, Tasso JB, Calchi AC, Machado RZ, et al. Evidence of exposure to Coxiella burnetii in neotropical free-living cervids in South America. Acta Trop 2019; 197: 105037. http://dx.doi.org/10.1016/j.actatropica.2019.05.028. PMid:31128095. 